\title{
PENERAPAN PAKEM DALAM MEWUJUDKAN PENDIDIKAN KARAKTER BANGSA DI SD NEGERI 101801 DELITUA KABUPATEN DELI SERDANG
}

\author{
Suharni \\ Surel: suharni@gmail.com
}

\begin{abstract}
ABSTRAK
Tujuan dari kegiatan PTS ini adalah untuk: a) Meningkatkan pemahaman Guru dalam mengembangkan PAKEM; b) Meningkatkan keterampilan Guru dalam mengembangkan PAKEM; dan c) Meningkatkan keterlaksanaan nilai pembentukan karakter bangsa dalam kegiatan belajar mengajar. Hasil analisis menunjukkan bahwa peningkatan pemahaman dan keterampilan guru tentang penerapan PAKEM dalam kegiatan belajar mengajar berimplikasi pada peningkatan partisipasi atau keaktifan siswa serta terhadap keterlaksanaan nilai-nilai pembentukan karakter bangsa, seperti nilai kerja keras, kerjasama, saling menghargai dan sebagainya. Metode penelitian ini adalah penelitian tindakan kelas.
\end{abstract}

Kata Kunci : Kegiatan Belajar, PAKEM, Pembentukan Karakter Bangsa

\section{PENDAHULUAN}

Pembukaan Undang-Undang

Dasar Negara Republik Indonesia Tahun 1945 mengamanatkan Pancasila sebagai dasar negara dan pandangan hidup bangsa Indonesia yang harus menjiwai semua bidang pembentukan. Salah satu bidang pembentukan nasional yang sangat penting dan menjadi fondasi kehidupan bermasyarakat, berbangsa, dan bernegara adalah pembentukan karakter bangsa. Pembentukan nasional yang selama ini dilaksanakan telah menunjukkan kemajuan di berbagai bidang kehidupan masyarakat, yang meliputi bidang sosial budaya dan kehidupan beragama, ekonomi, ilmu pengetahuan dan teknologi, politik, pertahanan dan keamanan, hukum dan aparatur, pembentukan wilayah dan tata ruang, penyediaan sarana dan prasarana, serta pengelolaan sumber daya alam dan lingkungan hidup. Namun, di samping banyak kemajuan yang telah dicapai ternyata masih banyak masalah dan tantangan yang belum sepenuhnya terselesaikan, termasuk kondisi karakter bangsa yang akhir-akhir ini mengalami pergeseran.

\section{Pembentukan}

Karakter Bangsa yang sudah diupayakan dengan berbagai bentuk, hingga saat ini belum terlaksana dengan optimal. Hal itu tecermin dari kesenjangan sosial-ekonomi-politik yang masih besar, kerusakan lingkungan yang terjadi di berbagai di seluruh pelosok negeri, masih terjadinya ketidakadilan hukum, pergaulan bebas dan pornografi yang terjadi di kalangan remaja, kekerasan dan kerusuhan, korupsi yang dan merambah pada semua sektor

Kepala SD Negeri 101801 Delitua 
kehidupan masyarakat. Saat ini banyak dijumpai tindakan anarkis, konflik sosial, penuturan bahasa yang buruk dan tidak santun, dan ketidaktaataan berlalu lintas. Masyarakat Indonesia yang terbiasa santun dalam berperilaku, melaksanakan musyawarah mufakat dalam menyelesaikan masalah, mempunyai kearifan lokal yang kaya dengan pluralitas, serta bersikap toleran dan gotong royong mulai cenderung berubah menjadi hegemoni kelompok-kelompok yang saling mengalahkan dan berperilaku tidak jujur. Semua itu menegaskan bahwa terjadi ketidakpastian jati diri dan karakter bangsa yang bermuara pada (1) disorientasi dan belum dihayatinya nilai-nilai Pancasila sebagai filosofi dan ideologi bangsa,

(2) keterbatasan perangkat kebijakan terpadu dalam mewujudkan nilai-nilai esensi Pancasila, (3) bergesernya nilai etika dalam kehidupan berbangsa dan bernegara, (4) memudarnya kesadaran terhadap nilai-nilai budaya bangsa, (5) ancaman disintegrasi bangsa, dan (6) melemahnya kemandirian bangsa.

Memperhatikan situasi dan kondisi karakter bangsa yang memprihatinkan tersebut, pemerintah mengambil inisiatif untuk memprioritaskan pembentukan karakter bangsa. Pembentukan Karakter Bangsa seharusnya menjadi arus utama pembentukan nasional. Artinya, setiap upaya pembentukan harus selalu dipikirkan keterkaitan dan dampaknya terhadap Pembentukan karaker. Hal itu tecermin dari misi pembentukan nasional yang memosisikan pendidikan karakter sebagai misi pertama dari delapan misi guna mewujudkan visi pembentukan nasional, sebagaimana tercantum dalam Rencana Pembentukan Jangka Panjang Nasional Tahun 2005-2025 (Undang-Undang Republik Indonesia Nomor 17 Tahun 2007), yaitu terwujudnya karakter bangsa yang tangguh, kompetitif, berakhlak mulia, dan bermoral berdasarkan Pancasila, yang dicirikan dengan watak dan prilaku manusia dan masyarakat Indonesia yang beragam, beriman dan bertakwa kepada Tuhan Yang Maha Esa, berbudi luhur, bertoleran, bergotongroyong, berjiwa patriotik, berkembang dinamis, dan berorientasi ipteks.

Pembentukan Karakter Bangsa memiliki urgensi yang sangat luas dan bersifat multidimensional. Sangat luas karena terkait dengan Pembentukan multiaspek potensipotensi keunggulan bangsa dan bersifat multidimensional karena mencakup dimensi-dimensi kebangsaan yang hingga saat ini sedang dalam proses "menjadi". Dalam hal ini dapat juga disebutkan bahwa (1) karakter merupakan hal sangat esensial dalam berbangsa dan bernegara, hilangnya karakter akan menyebabkan hilangnya generasi penerus bangsa; (2) karakter berperan sebagai "kemudi" dan kekuatan 
sehingga bangsa ini tidak terombangambing; (3) karakter tidak datang dengan sendirinya, tetapi harus dibangun dan dibentuk untuk menjadi bangsa yang bermartabat. Selanjutnya, pembentukan karakter bangsa akan mengerucut pada tiga tataran besar, yaitu (1) untuk menumbuhkan dan memperkuat jati diri bangsa, (2) untuk menjaga keutuhan Negara Kesatuan Republik Indonesia (NKRI), dan (3) untuk membentuk manusia dan masyarakat Indonesia yang berakhlak mulia dan bangsa yang bermartabat.

\section{Pembentukan Karakter}

Bangsa harus diaktualisasikan secara nyata dalam bentuk aksi nasional dalam rangka memantapkan landasan spiritual, moral, dan etika pembentukan bangsa sebagai upaya untuk menjaga jati diri bangsa dan memperkukuh persatuan dan kesatuan bangsa dalam naungan NKRI. Pembentukan Karakter Bangsa harus dilakukan melalui pendekatan sistematik dan integratif dengan melibatkan keluarga; satuan pendidikan; pemerintah; masyarakat termasuk teman sebaya, generasi muda, lanjut usia, media massa, pramuka, organisasi kemasyarakatan, organisasi politik, organisasi profesi, lembaga swadaya masyarakat; kelompok strategis seperti elite struktural, elite politik, wartawan, budayawan, agamawan, tokoh adat, serta tokoh masyarakat. Adapun strategi pembentukan karakter dapat dilakukan melalui sosialisasi, pendidikan, pemberdayaan, pembudayaan, dan kerja sama dengan memperhatikan kondisi lingkungan dan kebutuhan masyarakat serta pendekatan multidisiplin yang tidak menekankan pada indoktrinasi.

Pembelajaran Aktif, Kreatif, Efektif, dan Menyenangkan. Aktif atau disingkat PAKEM merupakan proses pembelajaran guru harus menciptakan suasana sedemikian rupa sehingga siswa aktif bertanya, mempertanyakan, dan mengemukakan gagasan. Belajar memang merupakan suatu proses aktif dari si pembelajar dalam membangun pengetahuannya, bukan proses pasif yang hanya menerima kucuran ceramah guru tentang pengetahuan. Jika pembelajaran tidak memberikan kesempatan kepada siswa untuk berperan aktif, maka pembelajaran tersebut bertentangan dengan hakikat belajar. Dengan demikian melalui penerapan pendakatan PAKEM siswa didik untuk gemar membaca, belajar dengan sungguh-sungguh, mengerjakan sesuatu pekerjaan dengan sebaik mungkin, berupaya mendapatkan hasil trerbaik, bekerjasama dengan sesama teman dan hal-hal positip lainnya yang semuanya memiliki keterkaitan dengan indikator nilai-nilai pembentukan karakter bangsa.

Berdasarkan kenyataan di atas penulis mencoba mengadakan penelitian tindakan sekolah untuk mengetahui efektivitas penerapan 
pendekatan PAKEM dalam kegiatan belajar mengajar (KBM) di DI SDN. 101801 Delitua serta kaitannya dengan Pembentukan Karakter Bangsa

Tujuan khusus dari kegiatan penelitian tindakan sekolah ini adalah untuk mengetahui efevtivitas penerapan pendekatan PAKEM dalam KBM di SDN. 101801 Delitua Kabupaten Deli Serdang. Sedangkan tujuan umum dari kegiatan penelitian tindakan sekolah ini adalah untuk mengetahui model integrasi penerapan Pendidikan Karakter Bangsa dalam kegiatan belajar mengajar di SDN. 101801 Delitua.

\section{METODE PENELITIAN}

Populasi penelitian dalam Penelitian Tindakan Sekolah ini adalah seluruh guru di DI SDN. 101801 Delitua yakni sebanyak 17 orang. Karena keterbatasan waktu dan biaya, maka yang yang dijadikan subyek dalam penelitian ini hanya 3 orang, yakni 1 orang Guru Mata Pelajaran PKn, 1 orang Guru Mata Pelajaran Pendidikan Agama dan 1 orang Guru Mata Pelajaran Seni Budaya.

\section{Teknik Pengumpulan Data}

Teknik pengumpulan data dalam penelitian ini diperoleh melalui observasi dan catatan data lapangan, wawancara, hasil tes dan catatan hasil refleksi atau diskusi yang dilakukan oleh peneliti dan mitra peneliti. Penentuan teknik tersebut didasarkan ketersediaan sarana dan prasana dan kemampuan yang dimiliki peneliti dan mitra peneliti. Uraian lebih lanjut mengenai teknik-teknik pengumpulan data tersebut adalah sebagai berikut:

a. Penilaian Pre Tes dan Post Tes.

b. Observasi dan catatan data lapangan.

c. Catatan hasil refleksi.

\section{HASIL DAN PEMBAHASAN}

\section{Siklus 1}

Tujuan yang ingin dicapai dalam PTS ini adalah a) Meningkatkan pemahaman Guru DI SD Negeri 101801 Delitua dalam mengembangkan PAKEM; b) Meningkatkan keterampilan Guru DI SDN. 101801 Delitua dalam mengembangkan PAKEM; dan c) Meningkatkan keterlaksanaan nilai Pembentukan Karakter Bangsa dalam kegiatan belajar mengajar. Hasil analisis siklus 1 menunjukkan bahwa:

1) Dilihat dari aspek guru, tampak bahwa pada siklus 1 ini keterampilan guru dalam penerapan pendekatan PAKEM masih kurang. Ini terlihat dari masih kurangnya keterampilan guru dalam menentukan atau memilih metode dan media yang variatif dan dapat merangsang aktivitas siswa.

Data hasil penilaian RPP pada siklus 1 menunjukkan bahwa pencapaian skor nilai RPP mapel PKn adalah 24; mapel IPA 
memperoleh skor 22 dan mapel Seni Budaya memperoleh skor 22. Dengan demikian ketiga RPP tersebut masih dikatagorikan kurang baik.

Sedangkan berdasarkan data hasil observasi pelaksanaan KBM menunjukkan pencapaian nilai pelaksanaan pembelajaran mapel PKn pada siklus 1 adalah 69; mapel IPA mencapai skor 63 dan mapel Seni Budaya mencapai skor 65. Dengan demikian dalam pelaksanaan pembelajaran ketiganya juga masih dikatagorikan kurang baik.

2) Dilihat dari dari aspek siswa, terlihat belum adanya peningkatan parrisipasi siswa dalam kegiatan belajar mengajar. Berdasarkan data hasil observasi menunjukkan bahwa aktivitas siswa pada siklus 1 dalam mapel PKn baru mencapai rata-rata skor 5,79 (cukup), dalam mapel IPA baru mencapai rata-rata skor 5,59 (cukup) sedangkan dalam mapel Seni Budaya mencapai skor ratarata 5,33 (cukup,). Hal tersebut menunjukkan bahwa aktivitas siswa belum mencapai katagori baik sehingga perlu ditingkatkan.

3) Dilihat dari data keterlaksanaan nilai-nilai pembentukan karakter bangsa, terlihat belum banyak indikator nilai-nilai Pembentukan Karakter Bangsa yang dapat diwujudkan. Data hasil observasi menunjukkan bahwa dari 25 indikator nilai-nilai Pembentukan
Karakter Bangsa yang diteliti, dalam mata pelajaran PKn baru terlaksana 9 indikator atau $36 \%$, IPA mencapai 5 indikator atau $29 \%$ dan mapel Seni Budaya mencapai 7 indikator atau $28 \%$.

Berdasarkan hal tersebut, kegiatan yang masih perlu mendapat perhatian khusus dalam PTS ini pada siklus berikutnya adalah peningkatan keterampilan guru terutama dalam kaitannya dengan pemilihan metode dan media pembelajaran yang sesuai dengan pendekatan PAKEM. Hal ini sesuai dengan prinsip PAKEM bahwa proses pembelajaran harus mengedapankan keterlibatan siswa yang pelaksanaan diwujudkan dengan penerapan metode dan media pembelajaran yang variatif dan inovatif.

\section{Siklus II}

Berdasarkan hasil refleksi pada siklus 1, pada siklus 2 ini PTS lebih memfokuskan pada peningkatan keterampikan guru dalam penerapan PAKEM, terutama dalam penggunaan metode dan media pembelajaran yang mampu meningkatkan keaktifan siswa dalam kegiatan belajar mengajar. Hasil analisis siklus 2 menunjukkan bahwa:

1) Dilihat dari segi guru, tampak bahwa pada siklus 2 ini keterampilan guru dalam penerapan pendekatan PAKEM sudah mulai mengalami 
peningkatan terutama dalam kaitannya dengan pemilihan dan penggunaan metode pembelajaran. Namun, dalam hal pemilihan media terlihat masih kurang variatif dan kurang dapat merangsang aktivitas siswa. Data hasil penilaian RPP pada siklus 2 menunjukkan bahwa pencapaian skor nilai RPP mapel PKn adalah 31 (baik); mapel IPA: 26 (kurang baik) dan dalam mapel Seni Budaya: 28 (kurang baik). Sedangkan berdasarkan data hasil observasi pelaksanaan KBM menunjukkan pencapaian nilai pelaksanaan pembelajaran mapel PKn pada siklus 2 adalah 77 (Baik); mapel IPA mencapai skor 69 (kurang baik) dan mapel Seni Budaya mencapai skor 70 (kurang baik). Dengan demikian sekalipun terdapat skor nilai yang dikatagorikan kurang baik, namun bila dilihat skor perolehannya sudah ada peningkatan dibandingkan siklus sebelumnya.

2) Dilihat dari dari segi siswa terlihat adanya peningkatan parrtisipasi siswa dalam kegiatan belajar mengajar. Data hasil observasi menunjukkan bahwa aktivitas siswa dalam mapel PKn mencapai rata-rata skor 6,45 (cukup), dalam mapel IPA mencapai 6,31 (cukup) dan mapel Seni Budaya mencapai skor rata-rata 6,23 (cukup). Hal tersebut menunjukkan bahwa

aktivitas siswa telah mengalami peningkatan namun belum mencapai katagori baik sehingga perlu ditingkatkan.

3) Dilihat dari data keterlaksanaan nilai-nilai pembentukan karakter bangsa, terlihat adanya peningkatan keterlaksaaan indikator nilai-nilai Pembentukan Karakter Bangsa yang dapat diwujudkan. Data hasil observasi menunjukkan bahwa dari 25 indikator nilai-nilai Pembentukan Karakter Bangsa yang diteliti, pada siklus 2 ini dalam mata pelajaran PKn sudah terlaksana atau terlihat 15 indikator atau 60\%, IPA mencapai 13 indikator atau 52\% dan mapel Seni Budaya mencapai 14 indikator atau $56 \%$.

Berdasarkan hal tersebut, kegiatan yang masih perlu mendapat perhatian khusus dalam PTS ini pada siklus berikutnya adalah peningkatan keterampilan guru dalam kaitannya dengan pemilihan media pembelajaran yang sesuai dengan pendekatan PAKEM seperti kasus, cerita, film atau video, foto (analisis kasus) dan sebagainya disesuaikan dengan konteks materi yang diajarkan.

\section{Siklus III}

Pada siklus ini telah
dilaksanakan berbagai usulan
perbaikan yang disarankan pada
siklus sebelumnya. Hasil analisis data
menunjukkan adanya peningkatan
pencapaian nilai atau skor yang
p-ISSN 2407-4934
e-ISSN 2355-1747


cukup baik dan signifikan. Hasil pembahasan dan analisis data pada siklus- 3 adalah sebagai berikut:

1) Adanya peningkatan keterampilan dalam pembuatan rencana pembelajaran. Skor pencapaian nilai RPP mapel PKn pada siklus 3 meningkat dari 31 pada siklus 2 menjadi 35; sedangkan dalam mapel IPA dari 26 menjadi 33 dan dalam mapel Seni Budaya dari 28 menjadi 34.

2) Keterampilan guru tentang penerapan PAKEM semakin meningkat, terutama dalam kaitanya dengan pemilihan metode dan media pembelajaran. Skor pencapaian nilai Pelaksanaan Pembelajaran mapel PKn pada siklus 3 meningkat dari 77 pada siklus 2 menjadi 83; sedangkan dalam mapel IPA dari 69 menjadi 81 dan dalam mapel Seni Budaya dari 70 menjadi 82. Hal ini menujukkan adanya peningkatan keterampilan guru dalam melaksanakan KBM dari kurang baik menjadi baik.

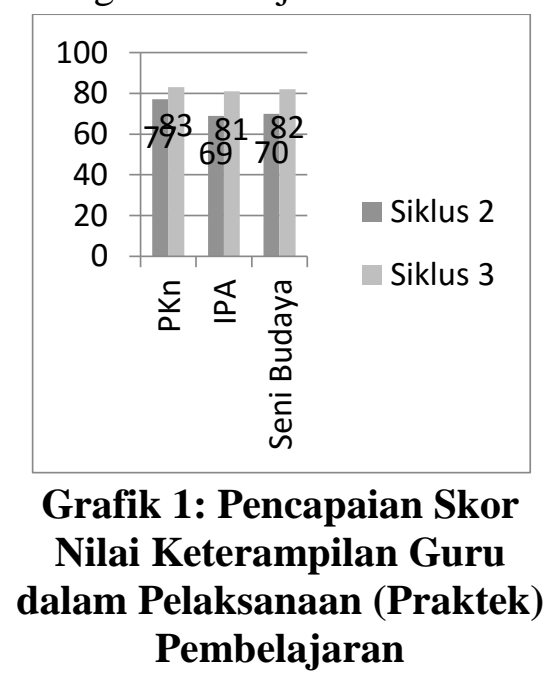

p-ISSN 2407-4934

e-ISSN 2355-1747
3) Perkembangan aktivitas siswa dalam kegiatan belajar mengajar mengalami peningkatan yang cukup berarti. Skor aktivitas siswa dalam KBM mapel PKn pada siklus 3 meningkat dari rata-rata 6,45 pada siklus 2 menjadi 9,31; sedangkan dalam mapel IPA dari 6,31 menjadi 9,17 dan dalam mapel Seni Budaya dari 6,23 menjadi 9,05.

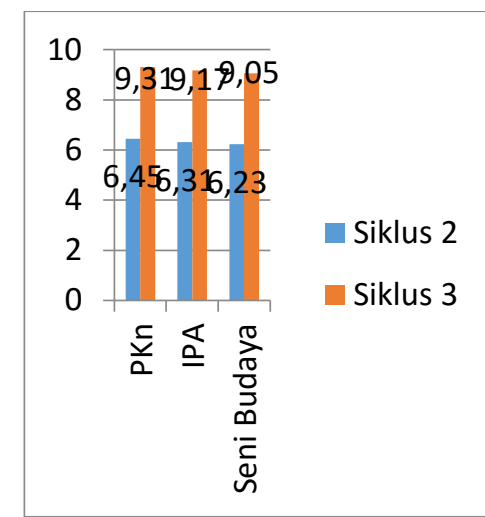

\section{Grafik. 2: Pencapaian Skor Rata-rata Aktivitasi Siswa dalam KBM}

4) Keterlaksanaan nilai-nilai Pembentukan Karakter Bangsa mengalami peningkatan yang cukup berarti sejalan dengan peningkatan pencapaian skor rata-rata aktivitas siswa. Data hasil observasi menunjukkan bahwa dari 25 indikator nilainilai Pembentukan Karakter Bangsa yang diteliti, pada siklus 3 ini dalam mata pelajaran PKn sudah terlaksana atau terlihat 24 indikator atau 96\%, IPA 
mencapai 22 indikator atau 88\% dan mapel Seni Budaya mencapai 23 indikator atau $92 \%$.

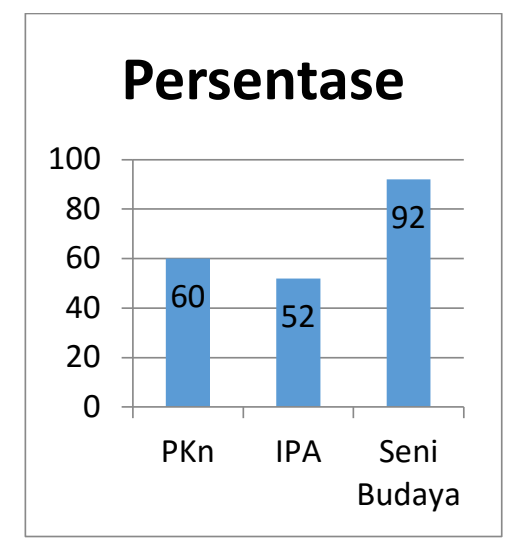

\section{Grafik 3: Pencapaian Keterlaksanaan Nilai-nilai Pembentukan Karakter Bangsa dalam KBM}

Berdasarkan hasil refleksi siklus 1, 2, dan 3 yang mencoba mengungkapkan keberhasilan maupun ketidakberhasilan kegiatan bimbingan yang dilakukan kepala sekolah terhadap guru-guru DI SDN. 101801 Delitua dalam penerapan pendekatan PAKEM dapat disimpulkan bahwa pemahaman dan keterampilan guru-guru DI SDN. 101801 Delitua tentang PAKEM mulai meningkat yang berimplikasi pula pada berkembangnya nilai-nilai pembentukan (pendidikan) karakter bangsa.

Hasil penelitian menunjukkan bahwa pengintegrasian pembentukan atau pendidikan karakter bangsa ke dalam semua mata pelajaran bukan merupakan sesuatu yang tidak dapat dilakukan, tetapi justru merupakan hal penting yang harus dilakukan. Bahkan selanjutnya pengintegrasian pembentukan atau pendidikan karakter bangsa harus terdapat dalam visi, misi, dan tujuan sekolah. Persoalan yang timbul dalam kaitannya dengan muatan pembentukan atau pendidikan karakter bangsa di kalangan guru (terutama di daerah) saat ini adalah kekhawatiran munculnya format RPP dan Silabus yang baru yang harus memasukkan pembentukan nilai-nilai karakter bangsa tersebut. Hal ini penting untuk kita pikirkan bersama agar kita tidak terjebak pada berbagai konstruksi yang tidak menyentuh akar persoalan yang kita hadapi.

Hasil penelitian ini sekalipun sangat sederhana menunjukkan bahwa pengintegrasian pembentukan atau pendidikan karakter bangsa ke dalam semua mata pelajaran tidak mesti dilakukan dengan mengadakan perubahan pada format atau komponen RPP yang harus dibuat oleh guru. Ini penting dilakukan untuk menghindari sikap apatis guruguru terhadap perubahan kurikulum yang disebabkan perubahan kurikulum yang terlalu cepat. Kita mesti bercermin bahwa rendahnya karakter bangsa kita saat ini adalah warisan yang banyak disumbangkan oleh model pendidikan karakter bangsa masa sebelum reformasi yang lebih banyak menekakan indoktrinasi dan penuh dengan muatan 'kekuasaan'. 
Oleh karena itu, mari kita benahi pembentukan atau pendidikan karakter bangsa dengan peningkatan keterampilan guru dalam mengelola kegiatan belajar mengajar dengan menerapkan pendekatan CTL, PAKEM dan lainnya yang menghindari praktek indoktrinasi. Dan yang tak kalah penting kita harus segera melakukan pembenahan sarana prasana pendidikan sehingga eksperimen guru untuk menerapkan pendekatan pembelajaran yang efektif dan menyenangkan tersebut akan mudah dilakukan.

Berdasarakan uraian di atas tampak bahwa hipotesis tindakan dalam PTS ini yang menyatakan “Apabila Penerapan Pendekatan PAKEM Dalam KBM di DI SDN. 101801 Delitua dapat berjalan efektif, maka keterlaksanaan nilai-nilai Pendidikan Karakter Bangsa akan meningkat." dapat diterima.

\section{SIMPULAN}

Berdasarkan hasil pelaksanaan penelitian tindakan sekolah (PTS) mengenai penerapan pendekatan Pembelajaran Aktif, Kreatif, Efektif dan Menyenangkan (PAKEM) langsung selama 3 siklus penelitian dapat disimpulkan:

1. Kegiatan bimbingan penerapan PAKEM bagi guru DI SDN. 101801 yang dilaksanakan kepala DI SDN. 101801 Delitua telah terlaksana dengan baik dan memberi kontribusi terhadap peningkatan pemahaman dan keterampilan guru tentang penerapan pendekatan PAKEM dalam kegiatan belajar mengajar.

2. Hasil analisis menunjukkan bahwa peningkatan pemahaman dan keterampilan guru tentang penerapan PAKEM dalam kegiatan belajar mengajar berimplikasi pada peningkatan partisipasi atau keaktifan siswa serta terhadap keterlaksanaan nilai-nilai pembentukan karakter bangsa, seperti nilai kerja keras, kerjasama, saling menghargai dan sebagainya.

3. Berdasarkan hasil refleksi, kegiatan PTS tentang Upaya Mewujudkan Pendidikan Karakter Bangsa Melalui Penerapan Pendekatan PAKEM Dalam KBM DI SDN. 101801 Delitua Kabupaten Deli serdang mencapai tujuan yang diharapkan yakni: a) Meningkatkan pemahaman Guru DI SDN. 101801 Delitua dalam mengembangkan PAKEM; b) Meningkatkan keterampilan Guru DI SDN. 101801 Delitua dalam mengembangkan PAKEM; dan 3) Meningkatkan keterlaksanaan nilai Pembentukan Karakter Bangsa dalam kegiatan belajar mengajar. Dengan demikian, hipotesis tindakan dalam PTS ini yang menyatakan "Apabila Penerapan Pendekatan PAKEM Dalam KBM di DI SDN. 101801 Delitua dapat berjalan efektif, maka keterlaksanaan nilai-nilai 
Pendidikan Karakter Bangsa akan meningkat." dapat diterima.

\section{DAFTAR RUJUKAN}

Direktoral Pendidikan Lanjutan Pertama. 2003. Pedoman Pembentukan Karakter Bangsa di Sekolah Lanjutan Tingkat Pertama, Direktorat Pendidikan Dasar dan Menengah. Jakarta: Depdiknas.

Depdiknas. 2009. Paket Pelatihan 1 Peningkatan Mutu Pendidikan Dasar melalui Manajemen Berbasis Sekolah, Peran Serta Masyarakat, Pembelajaran Aktif, Kreatif, Efektif dan Menyenangkan. Jakarta: Depdiknas.

Hasibuan dan Moedjino. 1996. Proses Belajar Mengajar. Bandung: Remadja Karya.

Hidayat, Kosadi, dkk. (1987). Strategi Belajar Mengajar Bahasa Indonesia. Bandung: Bina Cipta.

Kaifa, dkk. 2003. Penelitian Tindakan Kelas. Jakarta: Depdiknas.

Munandir. 2001. Kebijakan Nasional Pembanguan Karakter Bangsa 2010-2025. Malang: UM Press.

Silberman, Melvin, L. 2002. Active Learning, $101 \quad$ Strategi
Pembelajaran. Yogyakarta: Yappendis.

Sudirman, dkk. 1987.Ilmu Pendidikan. Bandung: Remadja Karya.

Tarsito, dkk. 1999. Filsafat Ilmu Sebuah Pengantar Populer. Jakarta: Pustaka Sinar Harapan.

Suhardjono, dkk. 1995. Pedoman penyusunan KTI di Bidang Pendidikan dan Angka Kredit Pembentukan Profesi Guru.Jakarta : Diknas.

Suhardjono. 2005. Laporan Penelitian Eksperimen dan Penelitian Tindakan Kelas sebagai KTI, makalah pada Pelatihan Peningkatan Mutu Guru.Makassar: LPMP.

Suharsimi, Arikunto. 1996. Prosedur Penelitian Suatu Pendekatan Praktek. Jakarta: Rineka Cipta

Suharsimi, dkk. 2006. Penelitian Tindakan Kelas. Jakarta : PT Bumi Aksara

Wiriaatmadja, dkk. 2005. Metode Penelitian Tindakan Kelas. Bandung: Rosdakarya.

Undang-Undang Republik Indonesia Nomor 14 Tahun 2005 Tentang Guru dan Dosen. 